\title{
Strategic and tactical aspect of the relations between the participants of ICP in high-rise construction
}

\author{
Maksim Fedorov ${ }^{1}$, Elena Matys ${ }^{1}$, and Anna Kopytova ${ }^{1 *}$, \\ ${ }^{1}$ Tyumen Industrial University, Volodarskogo str., 38, Tyumen, 625000, Russia
}

\begin{abstract}
Outlined the main trends in the development of the construction sector in the Russian Federation at the present stage of its development are identified problems and shortcomings of current investment in the construction industry. It is proved that to consider the investment and construction process should be in terms of the strategic and tactical aspects. It was established that, on the basis of the spirit and the participants of investment and construction process, the strategic aspect it should be focused primarily on the formation of financial resources (through various mechanisms) and to attract investors. A tactical aspect of the investment and construction process is focused on the choice of organizational form of the project and the rational use of resources generated by the investment in construction.
\end{abstract}

\section{Introduction}

Construction industry, closely connected with investment processes, has decisive importance for modern Russian economy, which suffers in recent years several problems, connected with sanctions, lack of financial resources and unstable currency rate. Construction is one of the industries with prolonged cycle of production, and capital investment problems may affect for a long-time period. The distinctive characteristic of investment and construction process is that construction companies act as accumulative organizations, which encourage investment from different sources in order to complete investment and construction project.

It is impossible to over valuate the importance of the construction industry for every single citizen of the country, as this industry brings not only construction results, but also working places, forms GDP, provides pumping up the budget on different levels. Economic and political reforms brought profound changes in the functioning of domestic investment and construction industry. Economic reform in the construction sphere became a fundamental change in optimality criteria in the construction and investment industry. New guidelines led to changes in both structure and measures in the activities of a construction company. List of participants changed and expanded, principle of mutual interaction became more complex, guidelines and objectives also changed. .

\footnotetext{
*Corresponding author: a.copytowa@yandex.ru
} 
In the new post-crisis ownership conditions, efficiency of the creation process of final construction products mostly depends on the concerted efforts and interaction between many participants of the investment and construction process: investors, customers, project-making and construction companies, material and equipment suppliers etc. The success of reaching the main goals - creation of final construction products and improvement of the cost, time and quality parameters, depends on effective organization and regulation of the interactions between stated above participants.

\section{Analysis of latest publications on the topic of research}

The problem of interaction between the investment and construction process participants is reviewed in works of specialists of a quite wide circle: economists, financiers, engineers, logistics experts, managers. Research on the chosen topic requires close focus on the works of the following scientists: V. Berens, I.A. Blank, A.H. Zaveryuha, A.V. Martynov, O.A. Menshikova, E.V. Ulianov, A.I. Ostashevskaya, E.A. Tkachenko, R.N. Holt, V.D. Shapiro

In is necessary to underline the fact that in recent years there are a lot of publications concerning construction problems, financial supply of the construction, realization risks of the investment projects in the sphere of finance, raise of the investment activity of the construction process participants. At the same time, the problem of specification of strategic and tactical directions of interaction between the investment process participants requires a more detailed review due to lack of publications on the given topic.

\section{Research goal}

On the basis of the description of the chosen topic and evaluation of the amount of works on the reviewed problem, it is possible to state the research goal: compilation of both theoretical and practical recommendations oriented on the formation of strategic and tactical directions of interaction between investment and construction process participants.

\section{Presentation of basic material of the research}

At the end of 2016, Russian economy shows several revival characteristics, though in general remains in the state of depression (Fig. 1).

According to The Ministry of Economic Development and Trade, GDP decrease in the first quarter of 2016 slowed down to $2.5 \%$, but, if seasonality is excluded, showed monthly decrease equal to $0.1 \%$. The GDP dynamics remained unchanged during the second quarter (- $0.6 \%$ annually) (Residential building and real estate market in the period of economic decrease (2016)). Positive development is shown by the third quarter, though GDP quantum index gives more information (comparison with the same quarter of the preceding year as $\%$ ), and it has not shown $100 \%$ and above since the end of 2014. Therefore, GDP increase in real prices is counter-balanced by inflationary processes.

Taking into account the fact that GDP index is the basic indicator of national economic development and mostly reflects the tendencies of most industries development, it is necessary to move forward to the analysis of the construction industry state in Russian Federation on the modern stage of development of the domestic economy. The construction sphere in Russia entered the crisis back in the second half of 2013, when stagnation of innovative process became evident in general. More than a half of all investments in Russia fall to housing ( $15 \%$ of all the investments in 2015 ) and non-residential buildings (41\%), and the housing share have been increasing starting from 2010. 


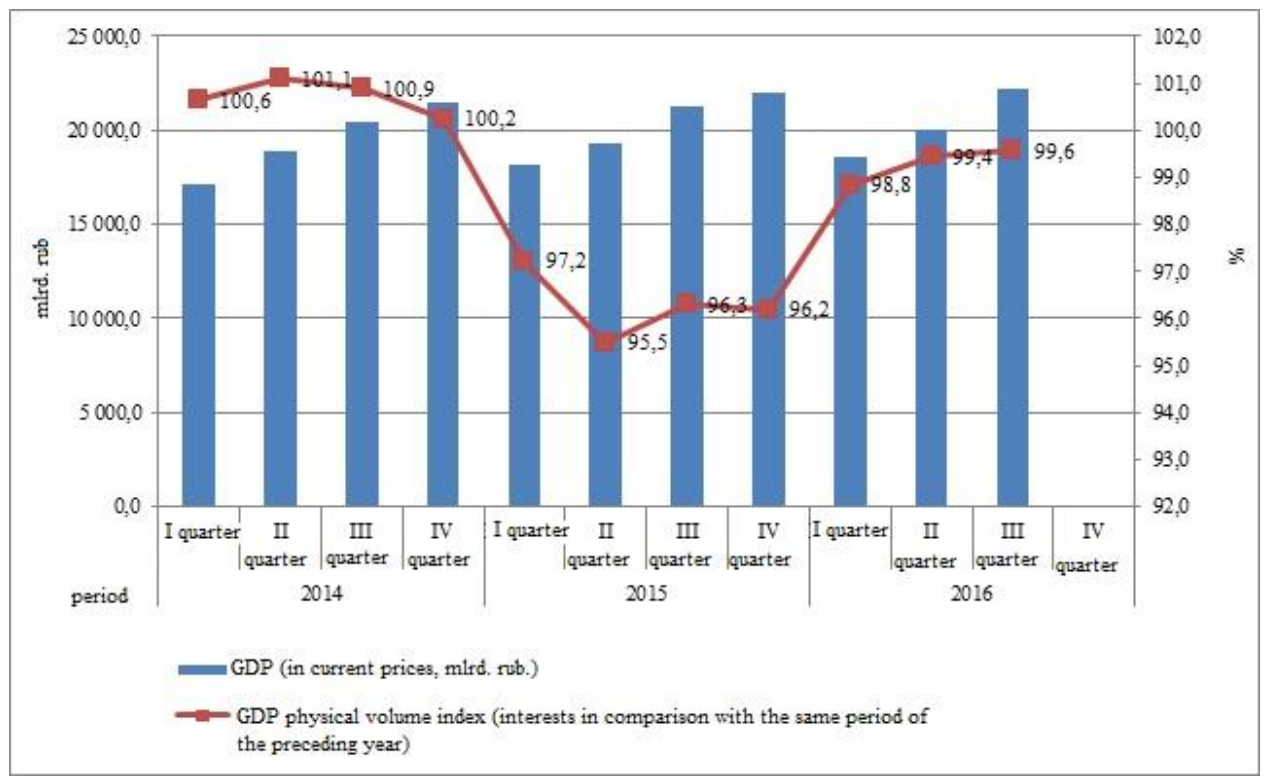

* made by the author on the basis of the Federal State Statistics Service data

Fig. 1 GDP dynamics in current prices and in interests compared with the same quarter of the preceding year

At the same time, according to the Federal State Statistics Service, overall investment volume in all economic spheres keeps on decreasing, and investments in capital stock (in other words, in construction), also decrease, though they are more unstable (pic. 2). Despite the fact that investments in construction increased in 2013, there is a significant decrease of this parameter since 2014 .

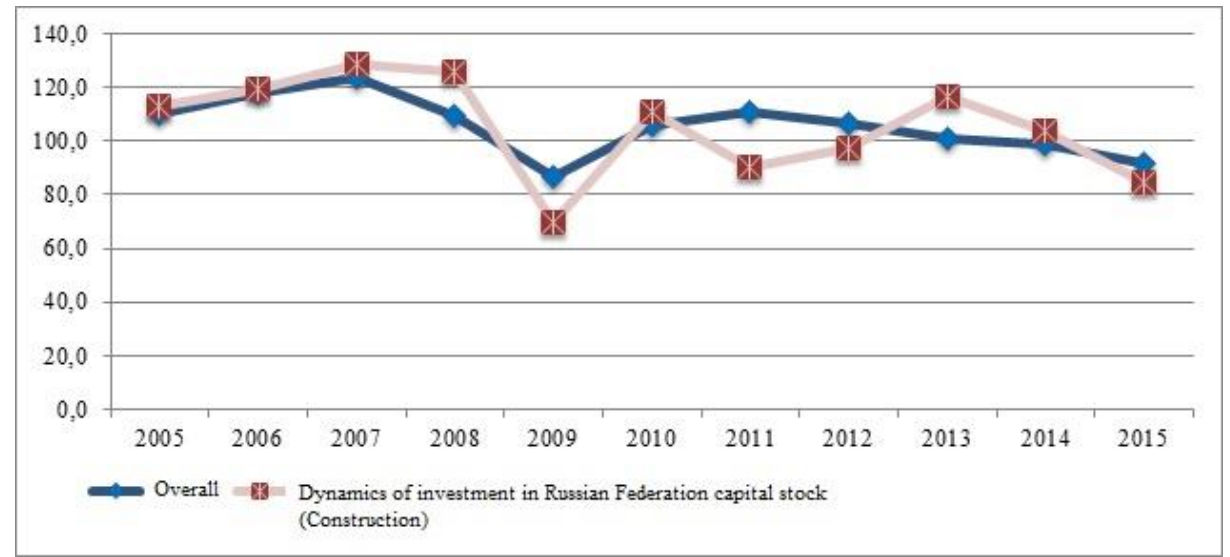

* made by the author on the basis of the Federal State Statistics Service data

Fig. 2 Comparison of investment in Russian Federation capital stock dynamics in all types of economic activity, in construction in particular

The first stage of overall investment decrease, including investments in the construction, happened in the period of world financial crisis in 2008-2009, when investment increase fell from $120 \%$ to $70 \%$, consequently affecting the domestic economy in general. As a result of 
smart policy of National Bank and profile ministries, the index raised back by 2010, though it didn't reach the pre-crisis figures. The crisis of 2014-15 influenced at the investment processes greatly. As a result, many foreign investors left the market, and domestic ones are not active due to unstable economy and national currency rate. Construction as a direction for long-time investments nowadays considered is a high-risk one.

It is considerable to evaluate volume and dynamics of the investments in the construction sphere particularly, which has been increasing in real prices since 2005, but index of physical volume of capital investments proves that the whole picture is not so bright (pic. 3 ). The problems can be traced back to 2012, when pace of capital investment growth slowed down. During last two years, experts note the tendency of slow capital investment decrease.

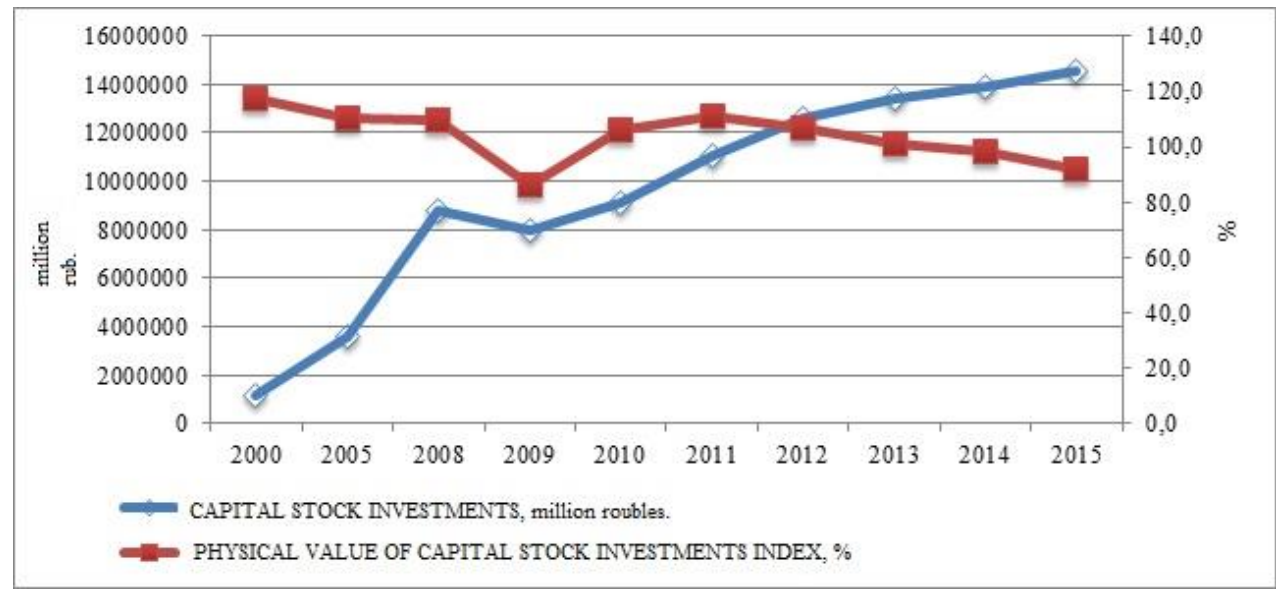

* made by the author on the basis of the Federal State Statistics Service data

Fig. 3. Dynamics of absolute and comparative values of capital stock investments.

Statistic data prove that it is necessary to develop effective mechanisms of investment improvement, especially in the construction sphere, as it is vital for residential, industrial and infrastructural construction, in other words, it reflects development of all branches of economic activity.

Systemic changes in the construction sphere should be started with development of strategic directions of investment activity, so it is necessary to note what influence on the relations between participants of the investment and construction process.

Contents of investment and construction processes as a single process come from the term "investment and construction complex", which has the following meaning:

Integration of construction and investment processes into one single complex;

Interaction between two activity types and consolidation of construction market participants and real investments;

Interaction or consolidation of constructive and real investment resources.

It is considerable to account the investment and construction process in theoreticaleconomic view as a system of relations between investment and construction cycle participants, concerning resource development and creation of material values. In business aspect, all participants of the investment and construction process fall into several groups:

Design organizations;

Enterprises;

Enterprises in the sphere of construction materials (brick factories, homebuilders, trusts etc.);

Infrastructure (transportation, energetics etc.). 
Special place in investment and construction process have the elements, the activity of those is connected with investment attraction. These are investment funds, investment banks, facilitating agencies and other structures. On a peculiar stage of economic development appears necessity of close analysis not of special organizations, but their specific combinations, which serve as inter-industry and branch complexes. In other words, investment and construction process is a peculiar set of relations between participants of investment activity, project, construction and installation works, concerning mobilization and rational use of resources. On the basis of conducted analysis, it is possible to distinguish the meaning of investment and construction process in strategic aspect. It turns out to be a set of all participants of investment and construction activity, oriented on the achievement of common goals

Investment and construction activity is practical (financial, organizational, productive, economic) activity of the government, incorporated and unincorporated businesses, connected with accumulation and achievement of financial resources in order to invest them in fixed assets and provide their effective usage. The amount of constructed and put in place fixed assets (buildings, constructions, objects) is defined by investors' abilities. These abilities are evaluated by size of capital investments, which investors are able to use in order to create fixed assets. Capital investment volume depends on the following factors:

Assets (owned capital) of investors, earned from business activity - profit, amortization, profit from capital issues etc.;

Opportunity and conditions of access to bank credits and other borrowed funds (funded loans, capital issues etc.), as well as use of population funds, attracted funds of labour collectives and incorporated businesses.

Economic rationality and ability of capital asset consolidation in within pool centers, finance and production groups, international companies; presence of investment potential of institutional structures such as pension funds and insurance companies.

Investment abilities of governmental and local budgets. Investment and construction complex should be considered as a set of economically, organizationally and technologically interconnected owned subjects, which common activity is oriented on putting in work capital funds of both productive and non-productive activity and satisfaction of own economic needs within the investment project realization.

Consequently, on the basis of meaning and participants of investment and construction process, it should be strategically oriented of financial resources formation (using various mechanisms) and investors attraction. The investors attraction problem should be solved not only by construction companies themselves, but also by the government by creation of favorable investment climate, attraction of institutional investors in the construction sphere and realization of domestic investors' stimulation mechanisms.

The problem of realization of investment policy is observed in T.R. Bareev's work (T.R. Bareev, 2015), which is devoted to the fact, that on the basis of investment policy's goals and taking into account structural priorities of economic development, it is possible to highlight its' main goals: increase of investment resources of the region on the basis of budget and non-budget sources of all levels of governmental management, financial resources of private domestic and foreign capital and population assets; concentration of investment resources on high-priority economic spheres and solution of the most actual social development problems by creation of favorable investment conditions; development and putting into practice market mechanism of investment process regulation; specified distribution of grace investments among chosen projects, economic sectors and territories; increase of investment supportability of depressing territories and stagnated branches (T.R. Bareev (2015)). Generalizing and systemizing all strategic approaches to the participants' of investment and construction process relations, it is possible to work out a scheme of the relations described above (Fig. 4). 
After all the strategic goals and directions of investment and construction process realization are defined, it is possible to move forward to development of tactical directions of this process' organization. On tactical level it is necessary to solve a larger amount of different problems, which arise on every stage of investment and construction project's realization.

According to the author, the primary direction within process of tactical problem's solution, which needs close attention, is choosing the form of organization of a construction project. The problems of realization of the given investment and construction process will be solved within the chosen form of organization

In Russian scientific research organizational form of investment and construction process' control is sometimes equal to organizational structure of the company. This approach is not correct. Participants of investment and construction process include many organizations of different specializations. It is a rare situation, when one company acts as customer, designer and contractor at the same time. Also one company is rarely able to provide the whole project with investment resources.

It is reasonable to take attention at the analysis of effectiveness of three main forms of investment and construction process: traditional, key ready and professional construction management. In organizational form of management in traditional contractual way the object's construction is made by specialized construction organizations (contractors), who sign an agreement with the customer.

Traditional form is connected with fixed price. It guarantees the project accomplishment in time within fixed (estimated) price, which is a high-risk one for the contractor, as he needs to forecast all possible problems, which may arise in the construction process at the stage of signing the agreement.

The experience of usage of traditional organizational form of investment and construction process organization shows for several years already that customers have to face such disadvantages as estimated price overrun and violation of estimated time of putting object into action. Moreover, in traditional form of construction control organization the customer has to execute many additional high-risk functions, not connected with his main activity profile. In other words, in traditional form of investment and construction process organization there is no function diversification depending on the final result of a given subprocess. Within this form, the customer signs a design project with one general contractor, who supplies the directors with main construction process phases: design and construction. It helps to speed up decision making and realization and, as a result, speeds up the construction and lowers the costs. General contractors are usually well-known design and construction organizations.

General contractor fully operates the resources and controls the construction process itself. As an alternative to traditional one, in foreign practice, key-ready organizational form of construction is considered as a mark of high professional skills level of all construction company personnel, a criterion of effective management system and solid advantage on investment and construction market. At the same time, it is necessary to understand the importance of shift to more progressive forms of participant relations organization on the basis of design and construction agreements, within which new demands to all investment process participants, contractors in particular, are set.

In modern countries in the latest decade rapidly develops the form of professional construction management (Fesenko T.G., Minaev D.M. (2016)). This form is an evolution of the key-ready form. Integration of design and construction stages, object complexity, necessity of further speeding up the construction, resulted as an introduction of new management type - professional construction management and its' particular operators professional managers. 


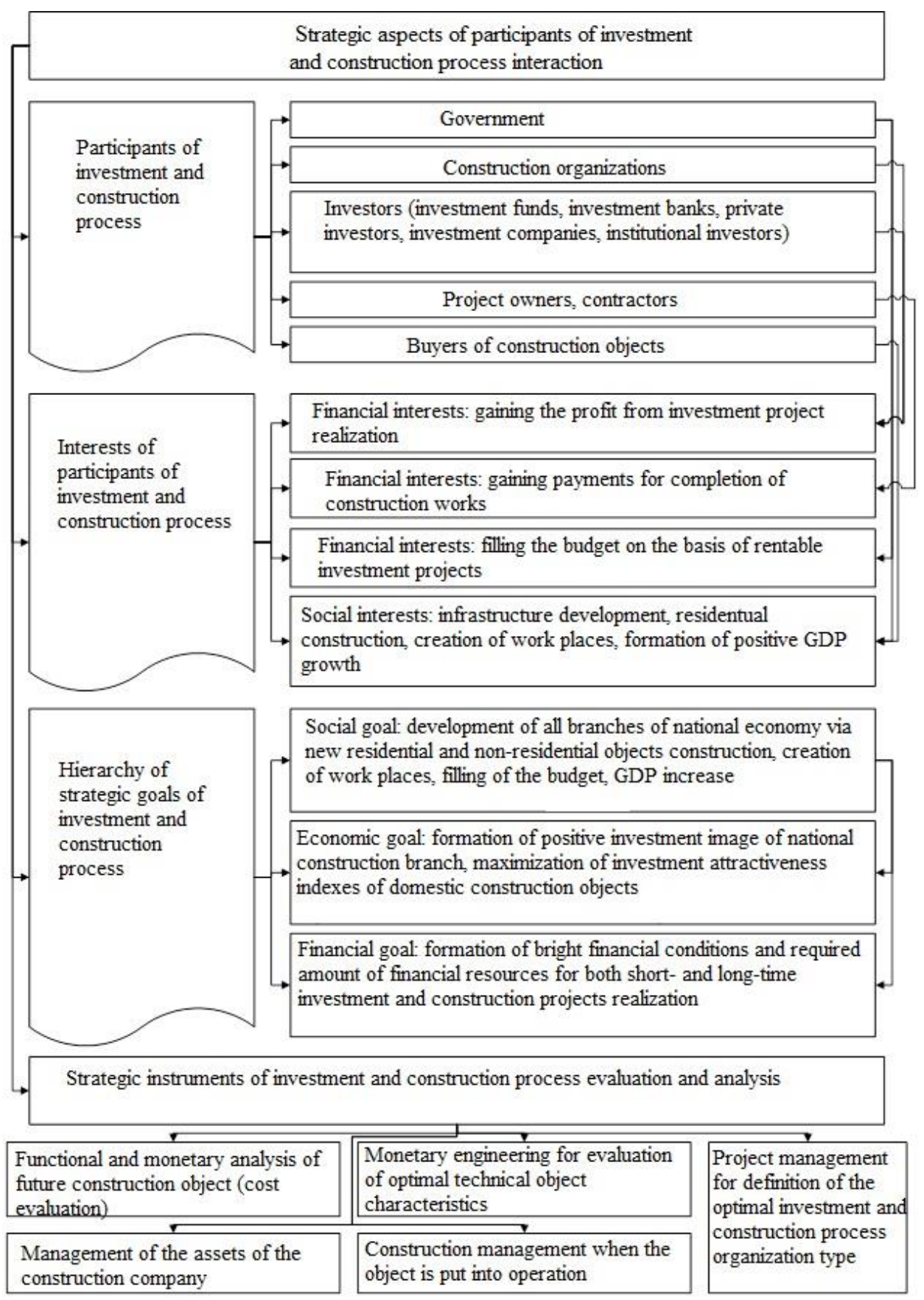

Fig. 4 Strategic aspects of participants of investment and construction process interaction (developed by the author) 
In unstable conditions of construction organizations environment, both customer's and investor's main goal is effective investment into new, perspective type of activity, development of new productions. One of the main criteria is quick investment refund. In this situation the customer gives control of the whole investment cycle to professional managers. While in modern countries the professional construction management and project management market is already formed, it is a still developing process for Russian construction sector, what is proven by the fact that traditional contractual customer-operator relations still prevail in the realization of the investment and construction process. The peculiarity of organizational form of professional construction management is that the customer, acting as both incorporated business and investor, signs all contract types with design and construction organizations, while planning, coordination and control over their realization is made by a professional manager. The same manager checks the quality of work and ensures rational usage of investor's financial resources.

Usage of professional construction management organizational form gives the customer all advantages of the key-ready form: opportunities to shorten the whole investment cycle by interaction of design and construction stages. The customer has an opportunity to control contractors' actions via construction manager, what decreases the risk of investment assets overrun, which form from investment resources.

For formalization of advantages of the choice of an organizational form within realization of tactical aspects of the investment and construction process we offer a methodical approach, which includes basic stages of choice of organizational form in a given situation (pic. 5).

Rationality and reasonability of usage of a chosen organizational form depends on objective factors. If financial resources are limited (and the company designed the project and has construction experience), it is not reasonable for the construction company to look for design and construction organization or hire a professional manager. In such situation it is reasonable to conduct a tender and find a contractor, who will do the work responsibly and for minimal price.

Along with design and construction companies attraction in the key-ready organizational form, it is possible to reach an effective work process and connect design and construction stages by hiring development companies, which provide construction within professional construction management form. Usage of a development company is oriented on effective organization of a construction process and profit increase from further object exploitation.

Developer is a businessman, who makes profit from construction object creation, where he acts as:

a) author of a project (what to create and where);

b) buyer of a land property for construction;

c) organizer of an object project process (made by licensed designers), employer of the customer, general contractor, brokers for object consignment, residential managers (if necessary) - gives financial resources himself or finds investors, if necessary.

There are two main development types within tactical realization of investment and construction process:

1) Developer doesn't cover financial risks and has a fixed fee (fee-development);

2) Developer creates commercial buildings, acting as a single organizer of the project.

Actually, developer completes structure and realization of financial scheme of the project. Developer may add into the project his own resources, which are an axis of future financial scheme, acting as investor at the same time. This development time is known as speculative development. The financial scheme of large development projects is usually a complex combination of developer's own resources, attracted investments, bank loans and payments from future residential owners 


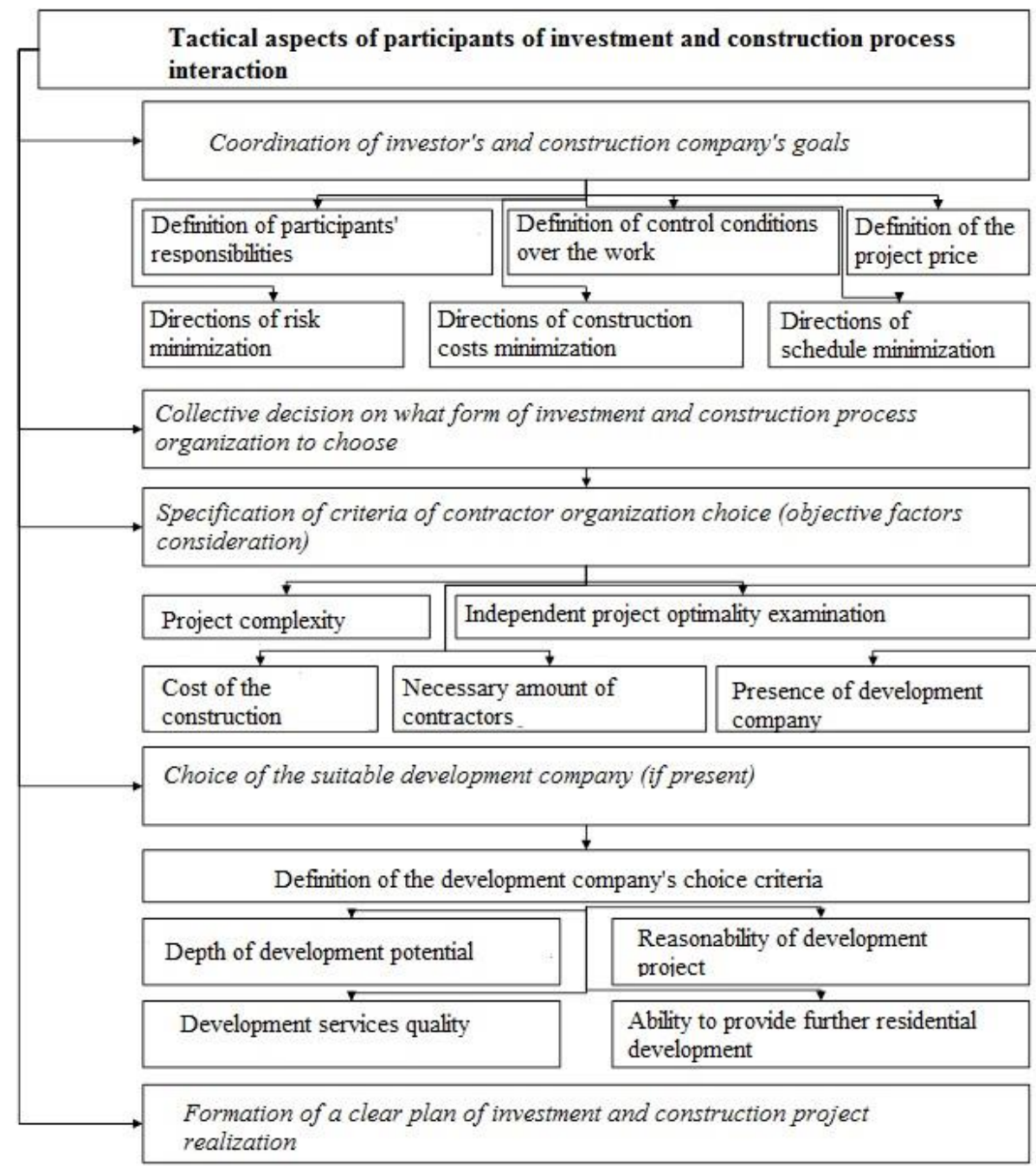

Fig. 5 Tactical aspects of participants of investment and construction process interaction (developed by the author)

Consequently, when company moves from traditional contractor form to professional construction management and key-ready forms, as well as reorganization of general contractor companies, significant part of responsibility is moved from highest level to the middle one.

The most responsible people, in modern understanding of investment and construction process, are situated on the level of contractors or developers, depending on the type of organizational form used. That is why general goals of the director of the construction in the process of design and construction process realization, along with action coordination of builders, subcontractors, material and equipment suppliers, are expanded by interaction with designer and investor.

The director of construction project implements the following functions:

Planning of design works according to the construction schedule;

Examination and evaluation of different design solutions on the stage of initial design, choice of the best one for customer's confirmation; 
Definition of the order of project documentation sets distribution;

Coordination of execution of design and construction schedule;

Registration and control of project changes in the construction process.

In is necessary to underline the fact that in recent years there are a lot of publications concerning construction problems, financial supply of the construction, realization risks of the investment projects in the sphere of finance, raise of the investment activity of the construction process participants. At the same time, the problem of specification of strategic and tactical directions of interaction between the investment process participants requires a more detailed review due to lack of publications on the given topic.

\section{Conclusion}

As a result, it is reasonable to highlight, that it is necessary for the company to use various methods, instruments and ways of construction activity organization in both tactical and strategic aspects in order to achieve successful realization of investment and construction process.

At strategic level it is necessary to coordinate interests of innovation and construction process participants, develop approaches of governmental stimulation of investors in construction sphere, provide maximization of investment attractiveness. The government is interested in investment and construction process activation, as it help to fill the budget, form GDP, develop infrastructure at different levels.

At tactical level the main goal is to choose the organizational form of investment and construction process support. As a rule, every of the forms described, provides the director of the construction with information related to a particular sphere. In conditions of dynamic foreign market, it is necessary to have a systematic approach to development of efficiency of construction production management, built on the interacted analysis of problem complex of various methods implementation.

It is necessary to highlight that with increase of the number of the investment and construction process participants and of interaction complexity, it is vital to develop management methods. That is why for successful realization of design and construction contracts, apart from organizational changes in management structure, it is necessary to have investor activity mechanisms and mechanisms of increase of national economy investment attractiveness.

\section{References}

1. M. Froli, F. Laccone, Journal of Architectural Engineering 24(1), 04017030 (2018) DOI: 10.1061/(ASCE)AE.1943-5568.0000285

2. J.M. Stritch, R.K. Christensen, International Journal of Manpower 37-5, 840-858 (2016) DOI: 10.1108/IJM-12-2014-0249

3. M. Gravit, O. Zybina, A. Vaititckii, A. Kopytova, Advances in Intelligent Systems and Computing 692, 1093-1101 (2018) DOI: 10.1007/978-3-319-70987-1_118

4. N. Zotkina, M. Gusarova, A. Kopytova, Advances in Intelligent Systems and Computing 692, 1204-1213 (2018) DOI: 10.1007/978-3-319-70987-1_129

5. M. TepePublic Management Review 18-4, 508-538

DOI: $10.1080 / 14719037.2015 .1014396$

$\begin{array}{lllllll}\text { 6. A. Kopytova, Procedia } & \text { Engineering } & \mathbf{1 6 5}, & 1132 & \text { (2016) } & \text { DOI: } \\ \text { 10.1016/j.proeng.2016.11.830 } & & & & & \end{array}$


7. A. Kopytova, MATEC Web of Conferences, 106, 08056 (2017) DOI: $10.1051 /$ matecconf/201710608056

8. N. Zotkina, S. Bardasov, M. Gusarova, A. Kopytova, MATEC Web of Conferences, 106, 08050 (2017) DOI: 10.1051/matecconf/201710608050

9. K. Pykhtin, T. Simankina, V. Sharmanov, A. Kopytova, IOP Conference Series: Earth and Environmental Science, 90 (1), 012065 (2017) DOI: 10.1088/17551315/90/1/012065

10. N.S. Zotkina, Finances and Credit 48 (480), 21-28 (2011)

11. V. Lezier, M. Gusarova, A. Kopytova, IOP Conference Series: Earth and Environmental Science, 90 (1), 012034 (2017) DOI: 10.1088/1755-1315/90/1/012034

12. A. Minnullina, R. Abdrazakov, Advances in Intelligent Systems and Computing 692, 1224-1233 (2018) DOI: 10.1007/978-3-319-70987-1_131

13. A.I. Kazannik, Bulletin of Omsk University 4 (33), 35-43 (2012)

14. A.V. Kopytova, Exchange of intellectual property 3 (XIV), 31-37 (2015)

15. B. Liu, J.L. Perry, Review of Public Personnel Administration 36-1, 4-30 (2016) DOI: $10.1177 / 0734371 X 14549672$

16. A. Minnullina, R. Abdrazakov, IOP Conference Series: Earth and Environmental Science, 90 (1), 012089 (2017) DOI: 10.1088/1755-1315/90/1/012089

17. J. Yeo, International Journal of Public Administration 39-3, 216-225 (2016) DOI: $10.1080 / 01900692.2015 .1004083$

18. M.S. Gusarova, A.V. Kopytova, Bulletin of Omsk University 4,14-22 (2014)

19. N.S. Zotkina, A.V. Kopytova, Economics and entrepreneurship 12-2(53-2),714-719 (2014)

20. V. Lezier, M. Gusarova, A. Kopytova, IOP Conference Series: Earth and Environmental Science, 90 (1), 012069 (2017) DOI: 10.1088/1755-1315/90/1/012069

21. A. Mottaeva, A. Minnullina, IOP Conference Series: Earth and Environmental Science, 90 (1), 012123 (2017) DOI: 10.1088/1755-1315/90/1/012123

22. M. Gravit, O. Zybina, A. Vaititckii, A. Kopytova, IOP Conference Series: Earth and Environmental Science, 90 (1), 012103 (2017) DOI: 10.1088/1755-1315/90/1/012103

23. E.A. Mitrofanova, Personnel and intellectual resources management in Russia 2, 36-41 (2014)

24. N. Zotkina, A. Kopytova, M. Zenkina, O. Zhigunova, MATEC Web of Conferences, 106, 08058 (2017) DOI: 10.1051/matecconf/201710608058

25. A. Minnullina, MATEC Web of Conferences, 106, 08067 (2017) DOI: $10.1051 /$ matecconf $/ 201710608067$ 